\title{
Perspectivizing pandemics: (how) do epidemic histories criss-cross contexts? ${ }^{\dagger}$
}

\author{
Anne-Emanuelle Birn \\ Centre for Critical Development Studies \& Dalla Lana School of Public Health, University of Toronto, 155 College St, Room \\ 558, Toronto, ON, M5T 3M7, Canada \\ Corresponding author. E-mail: ae.birn@utoronto.ca
}

\begin{abstract}
This article explores a smattering of thematic questions that criss-cross the articles in this special pandemics issue; it signposts some reverberations, overlapping responses, and problematic comparisons currently (mid 2020) being made between past pandemics and the tense experiences (and projections going forward) of COVID-19 across the world. The historical pandemics covered here offer an entry point to a fruitful set of genealogies, chronologies, epidemiologies, trajectories, and imaginaries linked to a host of issues: what makes a pandemic 'global'? What does a global history perspective bring to the table? How does examining germs and genomes shed light on imperialism as a/the pandemic driver? Where do animals, the environment, and ecology fit in and why are they so often excluded from pandemic histories? What counts as medical humanitarianism when health knowledge, know-how, and cooperation 'from below' are sidelined? And what came/comes first: a pandemic or a changed world?
\end{abstract}

Keywords: COVID-19; Ebola; global health; global history; history of public health; influenza; plague; smallpox

\section{Introduction: a historo-demic}

As the deathly drama of COVID-19 unfolds from one setting to another, historians and historical nuggets have become omnipresent secondary cast members. Those who practise history for a living, especially historians of medicine and public health, should be delighted, given our everdwindling interlocutors and audiences during regular times. Nowadays, the media and policymakers seek us out for insight, advice, roadmaps, possible endgames, forecasting, worst- and best-case scenarios, reassuring thoughts about scientific progress, and, almost always, 'lessons'. This golden opportunity for historians to share our windows on society is nothing to - ahem - cough at; even so, we must ask: how meaningful are both these requests and our interventions?

When the director-general of the World Health Organization (WHO), Dr Tedros Adhanom Ghebreyesus, observed in February 2020 that 'We're not just fighting an epidemic; we're fighting an infodemic', he did not include historical misrepresentation or oversimplification as part of the problem. ${ }^{1}$ Instead, he was referring to the current over-information, misinformation, disinformation, and rumours that together impede an effective public health response. Yet when painstakingly researched work is reduced to distorted and misleading summaries, light entertainment, and

\footnotetext{
${ }^{\dagger}$ I am grateful for the insights and suggestions of Kavita Sivaramakrishnan, Heidi Tworek, and Valerie Mendels.

${ }^{1}$ UN Department of Global Communications, 'UN tackles "infodemic" of misinformation and cybercrime in COVID-19 crisis', 31 March 2020, https://www.un.org/en/un-coronavirus-communications-team/un-tackling-\%E2\%80\%98infodemic\% E2\%80\%99-misinformation-and-cybercrime-covid-19. See also World Health Organization, 'Post-Conference: 1st WHO Infodemiology Conference', July 2020, https://www.who.int/teams/risk-communication/infodemic-management/postconference-1st-who-infodemiology-conference.
} 
facile armchair therapy, a quiet retreat to more sober and lonesome practices of preparing long monographs can be tempting. ${ }^{2}$

Fortunately, the collection of articles in this special issue serves as an antidote to this impulse, at one and the same time proffering historical complexity, original takes, timeliness, and relevance (whether hazy or patent) to current COVID-19 concerns. Having been summoned to prepare these reflections only after the editors convened the contributors, I do not presume to fully understand the logic behind the selection other than the point that the articles grapple with societal responses to each pandemic and/or its aftermath, and contemplate long-term consequences or how the disease 'changed the world', as the editors put it (debatably, I would argue). ${ }^{3}$ I also admit to being something of an interloper since my own research has been more preoccupied with public health politics, institutions, and endemic problems - such as infant mortality and hookworm - than with epidemics or pandemics per se.

Traversing era, place, and pandemic, this grouping of articles by historians and historically informed anthropologists and economists spans a wide swathe of the world and transcends the tiresome tale of north-centric (or middle-class-centric, for some pandemics) experiences as universal. Further, unlike the biomedically dominated WHO, and in a welcome departure from the mainstream media's mocking coverage, various of the articles here consider the legitimate role played by Indigenous healing and traditional forms of medicine. ${ }^{4}$

At first glance, it seems, the diseases are the central characters, comprising what we might call the big six, roughly chronologically: plague(s), smallpox, cholera, influenza(s), HIV/AIDS, and Ebola. Some might quibble that not all diseases covered in this issue (for example, smallpox) meet official pandemic criteria, ${ }^{5}$ or that crucial world-shaping vector-borne diseases (such as malaria) are missing. Yellow fever, which plagued the Americas for centuries, and recurs periodically in sub-Saharan Africa, is omitted from this and other pandemic collections, maybe because it transpired away from, and never threatened, the European locus of (past) power. Importantly, the pandemics/epidemics themselves are also an entry point to a far richer set of genealogies, chronologies, epidemiologies, and imaginaries of the many issues and trajectories brought to the fore; societies (and the divisions within them), perhaps more than pestilence, serve as the protagonists.

To state a truism for specialists, but not necessarily widely known, history is always subject to reinterpretation, and this special issue recognizes that historical pandemic reference points are in flux, as are the interlocutors, brokers, borders, and channels that define their parameters. This article explores a smattering of thematic questions that criss-cross the articles and evoke some of the tensions and commonalities experienced at the current (mid 2020) historical conjuncture: what does a global history perspective bring to the table? How does examining germs and genomes shed light on imperialism as a/the pandemic driver? Where does ecology fit in and why is it so often excluded from pandemic histories? What counts as medical humanitarianism when health knowledge and cooperation 'from below' are sidelined? And what came first: the pandemic or the changed world?

\footnotetext{
${ }^{2}$ For just one of a myriad of examples, see Donald G. McNeil Jr, 'Your Ancestors Knew Death in Ways You Never Will', New York Times, 15 July 2020, https://www.nytimes.com/2020/07/15/sunday-review/coronavirus-history-pandemics.html? action $=$ click\&module $=$ Opinion \&pgtype $=$ Homepage .

${ }^{3}$ Ewout Frankema and Heidi Tworek, 'Pandemics That Changed the World: Historical Reflections on COVID-19', Journal of Global History, 15 (2020): 333-335.

${ }^{4}$ Ironically, traditional healing measures receive more serious attention in scientific journals than at WHO. See for example, this peer-reviewed pharmacological analysis of how Chinese herbal medicine works: Yu-Feng Huang, Chen Bai, Fan He, Ying Xie, and Hau Zhou, 'Review on the Potential Action Mechanisms of Chinese Medicines in Treating Coronavirus Disease 2019 (COVID-19)', Pharmacological Research 158 (2020), https://doi.org/10.1016/j.phrs.2020.104939.

${ }^{5}$ Brook cites Sellwood on a pandemic's four distinguishing 'features: a novel pathogen, lack of public immunity, a high level of morbidity, and efficient transmission', amplified by a fifth: transmission beyond national, or at least regional, boundaries. Chloe Sellwood, 'Brief History and Epidemiological Features of Pandemic Influenza', in Introduction to Pandemic Influenza, ed. Jonathan Van-Tam and Chloe Sellwood (Wallingford, Oxon: CABI International Press, 2010), 41.
} 


\section{'Global' pandemics}

Although the term 'pandemic' (etymologically Greek, meaning 'all people', with the disease aspect presumed) denotes an outbreak that travels the world and crosses populations, a striking feature of COVID-19 communication is the frequent reference to a 'global pandemic'. This redundancy implies that a global foregrounding is essential both to (mis-)perceiving the present reality and to (mis-)understanding its historical antecedents.

Curiously (or perhaps to be expected), countless politicians, public health leaders, journalists, and members of the chattering classes have invoked historical morsels in ways that reproduce universalizing and unidimensional stories of pandemics in the past (typically based on EuroAmerican accounts). ${ }^{6}$ But what about historians themselves? Here we must interrogate the editors' multifarious use of 'global', as well as their assertion that the 1918-20 influenza is the 'pandemic that looms largest in the Euro-American collective comparative imagination', namely who is the 'collective', and what is being 'compared' and 'imagined'?' Given that not every country, colony, or community (even within the Euro-American ambit) was comparably affected (in India, as Chandra, Christensen, and Likhtman discuss, influenza was spread by British Indian troops along colonial railway lines; ${ }^{8}$ Brazil, which sent more soldiers to fight in the First World War than Argentina, was struck much harder; ${ }^{9}$ New Zealand, especially the Māori population, as Rice explains, experienced proportionately more deaths than Australia ${ }^{10}$ ), restraint is warranted.

Moreover, mortality figures sans denominators, such as those displayed on the ubiquitously cited Johns Hopkins COVID-19 dashboard, signal a certain demographic deceptiveness; ${ }^{11}$ population fluctuations and fear of unknown forms of death, illuminated by historians' ability to bring stories to the numbers, are not necessarily viewed similarly in distinct locales or historical moments. These are central concerns for global history, as covered in this special issue. Indeed, there is/was no consensus on what being 'affected' by the pandemic really means: is/ was this an immunological indicator? A physiological one? Emotional? Social? Spiritual? Political? Economic? These questions are ever more salient given that the never-ending (social) media coverage of COVID-19 is a sticky mix of contentions and reporting. Carrying this backwards, invocations of a lieu de mémoire to benchmark future suffering and attention misses the vital matter that remembrance and forgetfulness coexist even as they are discordant. ${ }^{12}$

Such measured insights contrast with the excess attention granted to the particular historical narrative of the US's 1918-19 influenza pandemic, including a US Department of Defense-funded study underlining the residual (and vague) category of 'non-pharmaceutical interventions'. ${ }^{13}$ This

\footnotetext{
${ }^{6}$ See, for example, Lydia McMullan, Garry Blight, Pablo Gutiérrez, and Cath Levett, 'How Humans Have Reacted to Pandemics through History: A Visual Guide', Guardian, 29 April 2020, https:/www.theguardian.com/society/ng-interactive/2020/apr/29/ how-humans-have-reacted-to-pandemics-through-history-a-visual-guide; David N. Durrheim and Michael G. Baker, 'COVID-19: A Very Visible Pandemic', Lancet 396, no. 10248 (2020), https://doi.org/10.1016/S0140-6736(20)31675-5.

${ }^{7}$ Frankema and Tworek, 'Pandemics That Changed the World: Historical Reflections on COVID-19', Journal of Global History, 15 (2020): 333-335..

${ }^{8}$ Siddharth Chandra, Julia Christensen, and Shimon Likhtman, 'Connectivity and Seasonality: The 1918 Influenza and COVID-19 Pandemics in Global Perspective’, Journal of Global History, 15 (2020): 408-420.

${ }^{9}$ Maria-Isabel Porras-Gallo and Ryan A. Davis, eds., The Spanish Influenza Pandemic of 1918-19: Perspectives from the Iberian Peninsula and the Americas (Rochester: University of Rochester Press, 2014); A. Carbonetti, 'Historia de una epidemia olvidada: la pandemia de gripe española en la Argentina, 1918-1919', Desacatos 32 (2010) : 159-74.

${ }^{10}$ Geoffrey Rice, 'How Reminders of the 1918-19 Pandemic Helped Australia and New Zealand Respond to COVID-19', Journal of Global History, 15 (2020): 421-433.

${ }^{11}$ Johns Hopkins University, 'COVID-19 Dashboard by the Center for Systems Science and Engineering', 2020, https:// coronavirus.jhu.edu/map.html.

${ }^{12}$ Mark Osborne Humphries, The Last Plague: Spanish Influenza and the Politics of Public Health in Canada (Toronto: University of Toronto Press, 2013). The author notes that smallpox was far more remembered than influenza.

${ }^{13}$ H. Markel, H. B. Lipman, J. A. Navarro, A. Sloan, J. R. Michalsen, A. M. Stern, and M. S. Cetron, 'Nonpharmaceutical Interventions Implemented by US Cities during the 1918-1919 Influenza Pandemic', Journal of the American Medical Association 298 (2007): 644-54.
} 
language implicitly privileges a biomedical magic bullet and is associated with the uniform call for 'flattening the curve' via lockdowns and behavioural measures to keep hospitals from being overwhelmed. Yet this Benthamite and assumption-ridden strategy overlooks the racialized, feminized, and working-class populations who have (had) to continue to work, commute, and/or live in crowded and dangerous conditions (for whom distancing, safely ventilated spaces, and home-as-shelter may represent a luxury). ${ }^{14}$

At bottom, the 1918-20 influenza pandemic increasingly seems a faulty analogy for guiding current responses: the virus has not dissipated over (northern hemisphere) summer months, and much of the public has been misled into regarding curve-flattening as an endgame rather than one prong of an evolving strategy. Moreover, where early and targeted testing/identification of cases, thorough contact tracing, and invigilated isolation have been adopted (most effectively in Taiwan), shutdowns have been averted and the outbreak controlled. This points to the dangers of overreliance on and overdetermination of a single historical/immunological experience, and of putting too much emphasis on (an elusive goal of) an über-powerful vaccine. ${ }^{15}$ Along the way, such a reductive approach to staving off the worst of the pandemic risks jeopardizing a mounting, if hardly novel, mobilization for the creation of socially just societies, in which safe and equitable housing, education, healthcare, and work are part of redressing long-standing racist, patriarchal, and classist social and occupational hierarchies, care-giving responsibilities, living conditions, and power and money asymmetries writ large.

If gauging the influence of histories of 1918-20 influenza on the polity or policy-makers is nigh impossible (Rice's Australia and New Zealand analysis being an obvious outlier), historians can make other discernments. As Peckham shows, the largely overlooked 1968 influenza pandemic, a not-so-near-miss (given 1 million deaths in a world of 3.5 billion people), has far greater historical bearing on both epidemiological and preparedness grounds. ${ }^{16}$ Against a backdrop of advances in virology and dramatic political uprisings across the globe, the Cold War's rivals bolstered pandemic planning and collaborated with the WHO, ushering in a modern system of worldwide viral surveillance and rapid vaccine production. The USSR focused on prophylaxis and epidemic predictions to confront the outbreak, ${ }^{17}$ while US public health authorities geared up surveillance (pre-emptively busting the myth of the demise of infectious diseases in high-income countries), continuing to pinpoint Asia as the source of pandemic perils. Yet, as Sivaramakrishnan argues, preparedness was never universalized in an 'enemy from away' sense, and pandemics merged interchangeably with epidemic and endemic concerns. ${ }^{18}$ In India, for instance, disease planning was part of a past and present consciousness that at any moment an outbreak could threaten the country's postcolonial scientific and economic trajectory; as such, not only experts but also the public were enlisted as responsible parties in protecting the country and its modernizing destiny. Political authorities sought to distribute risk relating to epidemics among the public, and to urge 'cooperative citizenship' and self-reliance, conveniently shielding the state from shouldering full moral and policy accountability. Clearly global history approaches give ample space to the upending of assumptions.

\footnotetext{
${ }^{14}$ Rachel L. Berkowitz, Xing Gao, Eli K. Michaels, and Mahasin S. Mujahid, 'Structurally Vulnerable Neighbourhood Environments and Racial/Ethnic COVID-19 Inequities', Cities \& Health (2020), https://doi.org/10.1080/23748834.2020. 1792069.

${ }^{15}$ Els Torreele, 'The Rush to Create a COVID-19 Vaccine May Do More Harm than Good', 5 August 2020, https://blogs. bmj.com/bmj/2020/08/05/the-rush-to-create-a-covid-19-vaccine-may-do-more-harm-than-good/.

${ }^{16}$ Robert Peckham, 'Viral Surveillance and the 1968 Hong Kong Flu Pandemic', Journal of Global History, 15 (2020): 444-458.

${ }^{17}$ V. M. Ždanov and I. V. Antonova, 'The Hong Kong Influenza Virus Epidemic in the USSR', Bulletin of the World Health Organization 41 (1969): 381-6.

${ }^{18}$ Kavita Sivaramakrishnan, 'Endemic Risks: Influenza Pandemics, Public Health, and Making Self-Reliant Indian Citizens', Journal of Global History, 15 (2020): 459-477.
} 
Then there is the question of the cultural crafting of a global 'imagination'. As Brook holds for plague, the grip of the Black Death on the Anglo-Saxon narrative of the rise of the West rests heavily on the abundant plague literature of Tudor and Stuart England, when 'writers put the disease to use as moral demonstration, escapist entertainment, and political critique'. But he finds no such evidence for a Chinese literary gaze on its coterminous experience with the second plague pandemic (thirteenth to seventeenth centuries): disease was 'part of the wallpaper of Ming times, not a shaping factor', and 'modernity' instead 'was forged in opposition to the perfidious West, without a pathogen in sight'. ${ }^{19}$ While this is disputable - given the rise of China's hygiene movement in response to the 'sick man of Asia' characterization in connection with the 1910 Manchurian plague outbreak ${ }^{20}$ - the point stands, as Brook concedes, that wielding public health tools of quarantine and face masks during a local epidemic not a globalizing one (Black Death or 1918 influenza), then and now, displays China's 'state-led modernity' in the face of Western critique.

\section{$\ldots$ and global history}

This leads us to the potential posing of a 'royal we' in global history. Here it is worth pausing to remind readers of, or familiarize them with, what this approach unlocks and what it potentially sidesteps or forecloses. Despite some conflation, global history differs from world history, the former rejecting the latter's linear and broad narratives around convergence (or centrifugal diffusion) of values, social, political, and economic journeys, and 'civilizations' ${ }^{21}$ By contrast, global history seeks to do away with singular accounts and to decentre states and institutions even as it recognizes the role of uneven power. Global history is not strictly comparative, but rather acknowledges interactions, exchanges, ties, and networks in creating 'simultaneities' in distinct and multiple locales.

All of this bodes well for the history of global health and of pandemics, ${ }^{22}$ though Sivaramakrishnan, among others, cautions that the mapping of such processes (and reliance on the primary sources and historiography most accessible) may reproduce centrism and a 'West and the rest' gulf. ${ }^{23}$ Enriched by transnational history, ${ }^{24}$ the historical study of pandemics from a global perspective ought to be able to transcend these concerns, but a challenge remains: escaping global history's association with the language and processes of globalization, whose pervasiveness continues to provoke totalizing and anxiety-producing connotations in vernacular and academic discourse alike. ${ }^{25}$

Given lively critiques that transnational and global history frames may inexorably distil into triumphalist 'convergence stories', the articles herein remind us that place-based histories remain crucial (recalling Pasteur's apocryphal deathbed quote, 'the microbe is nothing, the terrain is everything'), and that an all-encompassing optic is impossible: every account is inclusive/exclusive

\footnotetext{
${ }^{19}$ Timothy Brook, 'Comparative Pandemics: the Tudor-Stuart and Wanli-Chongzhen Years of Pestilence, 1567-1666', Journal of Global History, 15 (2020): 363-379.

${ }^{20}$ Ruth Rogaski, Hygienic Modernity: Meanings of Health and Disease in Treaty-Port China (Berkeley: University of California Press, 2014).

${ }^{21}$ Sebastian Conrad, What Is Global History? (Princeton: Princeton University, 2016), 63; and Tatyana L. Shestova, 'Methodological Foundations of Global History', Globalistics and Globalization Studies (2013): 180.

${ }^{22}$ See, for example, Bashford, Alison, ed., Medicine at the Border: Disease, Globalization and Security, 1850 to the Present (New York: Palgrave Macmillan, 2006).

${ }^{23}$ Kavita Sivaramakrishnan, 'Global Histories of Health, Disease, and Medicine from a 'Zig-Zag' Perspective', Bulletin of the History of Medicine 89 (2015): 700-4.

${ }^{24}$ Fiona Paisley and Pamela Scully, Writing Transnational History (London: Bloomsbury Publishing, 2019). See also PierreYves Saunier, Transnational History (Basingstoke: Palgrave Macmillan, 2013); Akira Iriye, Global and Transnational History: The Past, Present, and Future (Basingstoke: Palgrave Macmillan, 2013).

${ }^{25}$ A. Appadurai, 'Grassroots Globalization and the Research Imagination', in Globalization, ed. A. Appadurai (Durham, NC: Duke University Press, 2001), 1-21.
} 
by definition. ${ }^{26}$ Further, living and writing amid a pandemic forces historians into an unfamiliar reflexivity that escalates our empathy to past protagonists - and their lived realities of uncertainty, fears, spatial barriers, and realigned solidarities. This exercise also transforms the global historian from cosmopolitan bird's-eye analyst to worm's-eye parochialist who is challenged to recreate collective experiences when they are particular. With the loss of the pan-optic, we gain an intimate sense of a shared ordeal even if it differs by place, social class, occupation, and a host of racialized, gendered, and cultural characteristics. Still, unlike anthropologists, historians (especially overly empathic ones) who place themselves in their own narratives risk scorn if newly emerged sources contradict their interpretations. ${ }^{27}$

This troubling of the global history project is not meant to detract from the important mission and many contributions showcased in this special issue. Indeed, we are presented with interesting parallels of experience, impact, and historical significance (and to a lesser extent drivers) of outbreaks on a grand scale. A strong dialogic dimension emerges (across diseases and articles), noting that comparing epidemics and societal reactions over time and place is, ironically, both fraught and instructive. ${ }^{28}$ As several authors elegantly demonstrate, the comparative endeavour entails contested or at least complicated chronologies of the way that things were (or are). Chandra, Christensen, and Likhtman, for example, synthesize a synchronicity of 1918-20 influenza waves, marked by both antipodally informed seasonalities (hoped-for but doubtful for COVID-19) and overarching early twentieth-century connectivities involving war, trade, and colonial networks, all with transposed relevance today.

\section{Germs, genomes, and empires}

Asserting resonance with past disease outbreaks, whether linked to communication, patterns of unequal exposure and impact, repression, or policy reputation, is harder for some. Harper - not surprisingly a specialist of Roman pandemics - jokingly admits to 'disappoint[ing] history buffs everywhere by sharing the home truth that we are, for better or worse, not the Roman empire'. ${ }^{29}$ And yet, as he himself demonstrates, the fields of palaeogenomics (the study of ancient genetic material) and phylogenetics (the study of how relationships between species or populations have evolved) defy this distance, showing where and how pathogens have travelled with much greater detail and certainty than that enabled by the historians' typical documentary tools. This budding field of inquiry is poised to do far more than indicating connections, instead forcing a rewriting of history in some cases and obliging political, social, intellectual, and other historians to finally pay closer attention to how public health, medical, environmental, and scientific histories are central to the historical endeavour.

As the cutting-edge work of the medievalist Monica Green's multi-disciplinary plague exploration uncovers, the study of germs that literally encapsulate history is generating 'a radically new interpretation of the origin of the Black Death, the plague pandemic that is generally considered

\footnotetext{
${ }^{26}$ Jeremy Adelman, 'What Is Global History Now?', Aeon, 2 March 2017, https://aeon.co/essays/is-global-history-stillpossible-or-has-it-had-its-moment. A vibrant debate on this issue is Richard Drayton and David Motadel, 'Discussion: The Futures of Global History', Journal of Global History 13, no. 1 (2018): 1-21.

${ }^{27}$ Among the most egregious cautionaries is Joseph Ellis' biography, American Sphinx: The Character of Thomas Jefferson (New York: Alfred A. Knopf, 1997), in which the author sanctimoniously compared his own physique, Virginia upbringing, shared alma mater, and moral probity to Jefferson. Since author and subject were 'kindred spirits', Ellis intimated, Jefferson could not possibly have fathered the children of the enslaved Sally Hemings. In 1998, a DNA study published in Nature by the retired pathologist Eugene Foster incontrovertibly toppled Ellis' 'character proof, confirming what Jefferson's contemporaries and Hemings' descendants have long known/considered to be the truth. See also Annette Gordon Reed, The Hemingses of Monticello: An American Family (New York: W. W. Norton \& Co., 2008).

${ }^{28}$ D. R. Nascimento, As pestes do século XX. Tuberculose e AIDS no Brasil, uma história comparada (The Plagues of the Twentieth Century: Tuberculosis and AIDS in Brazil - A History Compared) (Rio de Janeiro: Editora Fiocruz, 2005).

${ }^{29}$ Kyle Harper, 'Germs, Genomes, and Global History in the Time of COVID-19', Journal of Global History, 15 (2020): 350-362.
} 
the largest mortality event in human history'. ${ }^{30}$ Genetic evidence is transforming the second plague pandemic from a largely European and European borderlands (North Africa, Middle East, Central Asia) story - with diffusion from China as the (perennially blamed) source - into an entirely novel account with distinct timing, reach, roots, rationale, and methodology. Green's brilliant bio-history places the Black Death's origins in the early thirteenth century, not the fourteenth, and traces it to the (unintended) environmental consequences of repeated Mongol conquests westwards, north-eastwards, and eastwards, tying Central Asia's Tian Shan mountain range marmots to rodents hitchhiking in the invaders' grain sacks. After all, trade along China's Silk Road was never demonstrated as the route of plague transmission, only postulated to be so. Pre-modernists are uniquely qualified to connect such dots, since the dearth of sources forces them to be as open as possible to diverse kinds of evidence. Now historians, global health analysts, schoolteachers, Horrible Histories writers and graphic artists, ${ }^{31}$ and uneducated politicians alike will need a fundamental rethink of the trope of China as plague culprit, which has direct lines to the current Chinese 'sick man' blame game. ${ }^{32}$ This work also suggests that, just like medievalists, public health and political leaders grappling with the many unknowns of a new pandemic might reach for the complexities, not simple lessons, of historical experience to help forge the path ahead.

The new, decentred historiographies of plague remind us once again of the long tentacles of ascribing blame, stereotyping, and othering, ${ }^{33}$ and of how the historical sourcing of disease (to the East) begets historical interpretations so powerful that few historians have thought to challenge them.

This discovery also heightens the role of imperialism - and its coercive, racialized, and hierarchical aspects - as a crucial pandemic driver and connector, whether linked to the Iberian invasion of the 'Americas' combining germs, forced labour, and food $\mathrm{crises}^{34}$ or to British consolidation of imperial trade routes and abysmal colonial and working-class social conditions in the case of cholera, as per Huber's explanation of how international health efforts were circumscribed and reinforced prejudices against Middle Eastern players in order to preserve imperial privilege. ${ }^{35}$ Imperialism's role as pandemic conductor extends into and beyond the twentieth century, from the First World War's quintessential inter-imperial war-fanning, trade-linking, and empireconsolidating pandemic of influenza, as Chandra, Christensen, and Likhtman illustrate; to contemporary neoliberal hyper-global capitalism shepherding in Ebola - through a mix of historical patterns of enslavement and putative 'liberation' with today's extractive imperialism - as Richards forcefully argues; ${ }^{36}$ and the ways in which COVID-19 is currently unreeling along class, racial, gender, and occupational lines in multiple settings. In turn, these imperial imperatives impel

\footnotetext{
${ }^{30}$ Monica H. Green, 'Plague: The Mongols' Biggest Environmental Legacy' (paper presented at 'Temporal Continuities and Reflections', Durham Early Modern Conference (IMEMS), Durham University, 10 July 2020), cited with permission of the author.

${ }^{31}$ See Horrible Histories 'Perilous Plague' episode (2002), https://www.imdb.com/title/tt0976552/fullcredits.

${ }^{32}$ As Brook notes, the fact that Chinese scientists are not deeply engaged in genomic research on ancient DNA suggests a fear that uncovering origin stories of global pathogens inside China could lead to a re-casting of China as the 'sick man of Asia', while detracting from the 'narrative of an ancient, healthy, and unified Chinese race'.

${ }^{33}$ Human Rights Watch, 'Covid-19 Fueling Anti-Asian Racism and Xenophobia Worldwide', 12 May 2020, https://www. hrw.org/news/2020/05/12/covid-19-fueling-anti-asian-racism-and-xenophobia-worldwide; Kate Connelly, 'German Jewish Leaders Fear Rise of Antisemitic Conspiracy Theories Linked to COVID-19', Guardian, 21 July 2020, https://www. theguardian.com/world/2020/jul/21/german-jewish-leaders-fear-rise-of-antisemitic-conspiracy-theories-linked-to-covid-19.

${ }^{34}$ Anne-Emanuelle Birn, 'How to Have Narrative-Flipping History in a Pandemic: Views of/from Latin America', Centaurus 62, no. 2 (2020): 354-69.

${ }^{35}$ Valeska Huber, 'Pandemics and the Politics of Difference: Rewriting the History of Internationalism through NineteenthCentury Cholera', Journal of Global History, 15 (2020): 394-407.

${ }^{36}$ Paul Richards, 'Ebola and COVID-19 in Sierra Leone: Comparative Lessons of Epidemics for Society', Journal of Global History, 15 (2020): 493-507.
} 
us to home in on the interplay of humans with non-human (environmental and animal) worlds, not only in the Capitalocene but across all eras. ${ }^{37}$

\section{Bringing animals and the environment (back) into global health history}

As Harper stresses, the findings from historical genomics and phylogenetics can also operate in the other direction, pushing medical and public health historians to bridge the humanities(social) science (or history-biology-medical anthropology) divide. A critical element of this bridging is taking seriously the ecological history of zoonoses (diseases with animal hosts, constituting the overwhelming majority of pandemics). This is germane to human interactions with insects, livestock, domesticated animals, birds, and other wildlife, underscoring the fact that the threat is not always animal to human. As Harper notes, and early twentieth-century Uruguayan public health veterinarians observed, ${ }^{38}$ bovine tuberculosis derives from human tuberculosis (and transmits both ways); human-to-animal directionality of infection has also emerged with COVID-19 on Dutch, Spanish, and US mink farms (and the odd household pet). ${ }^{39}$

Today, the field of One Health (reinvigorated in 2005, after the 2003 SARS outbreak, albeit with a long Indigenous genealogy), which seeks to reintegrate human-oriented medicine, public health, and scientific research with both animal and environmental analogues, has made some inroads (though less so from a historical perspective). The ecological (or One Health) history of Ebola, for example, tells us much about how the political (extractive) economy, biology, labour, enslavement and international financial history intertwined to generate land and livelihood loss and facilitate the trilogy of animal-environmental-human spread of the disease, as discussed by Richards. ${ }^{40}$ The emerging political ecology studies of COVID-19 offer important instruction to those seeking to source the social, economic, agricultural, and environmental origins of pandemics. ${ }^{41}$ Ironically, the contributor who has most thought about bringing animals (back) into global (health) history, Martha Few, explores the vicissitudes of colonial inoculation campaigns against smallpox, the sole non-zoonosis in this collection. ${ }^{42}$ Nonetheless, animals are not completely absent: inoculation's successor vaccination, based on cowpox, serves as an epilogue to her story of colonialIndigenous tensions and contestations, and provides a prologue to the COVID-19 vaccination quick/slow fix that many are impatiently awaiting. All told, historians should better incorporate ecological dimensions into the overall architecture of pandemics.

\footnotetext{
${ }^{37}$ Monica H. Green, 'Emerging Diseases, Re-emerging Histories', Centaurus 62, no. 2 (2020): 234-47. On the preference for the term Capitalocene over Anthropocene, see Elmar Altvater, Eileen C. Crist, Donna J. Haraway, Daniel Hartley, Christian Parenti, and Justin McBrien, Anthropocene or Capitalocene? Nature, History, and the Crisis of Capitalism (Oakland, CA: PM Press, 2016).

${ }^{38}$ R. Muñoz Ximénez, 'La lucha contra la tuberculosis bovina', La Tuberculosis. Organo de la Liga contra la Tuberculosis en el Uruguay 8, nos. 9-10 (1910): 271-6.

${ }^{39}$ Eli Cahan, 'COVID-19 Hits U.S. Mink Farms after Ripping through Europe', Science, 18 August 2020, https://www. sciencemag.org/news/2020/08/covid-19-hits-us-mink-farms-after-ripping-through-europe.

${ }^{40}$ Gregg Mitman, 'Ebola in a Stew of Fear', New England Journal of Medicine 371, no. 19 (2014): 1763-5.

${ }^{41}$ R. Wallace, A. Liebman, L. F. Chaves, and R. Wallace, 'COVID-19 and Circuits of Capital', Monthly Review 72, no. 1 (2020), https://monthlyreview.org/2020/04/01/Covid-19-and-circuits-of-capital/; Howard Waitzkin, 'Confronting the Upstream Causes of COVID-19 and Other Epidemics to Follow', International Journal of Health Services (2020), https:// doi.org/10.1177/0020731420946612. Climate events may have helped drive the re-emergence of plague in Ming China (see Brook) and Meso-America's deadly 1545 cocoliztli epidemic, previously misidentified as smallpox. See R. AcuñaSoto, D. W. Stahle, M. K. Cleaveland, and M. D. Therrell (2002), 'Megadrought and Megadeath in 16th Century Mexico', Emerging Infectious Diseases 8 (2002): 360-2. Peckham, meanwhile, explains that preparing for, and responding to, the 1968 influenza outbreak focused on surveillance of the disease's animal reservoirs.

${ }^{42}$ Martha Few, 'Epidemics, Indigenous Communities, and Public Health in the COVID-19 Era: Views from Smallpox Inoculation Campaigns in Colonial Guatemala', Journal of Global History, this issue, 380-393. See also Martha Few and Zeb Tortorici, Centering Animals in Latin American History (Durham, NC: Duke University Press, 2013).
} 


\section{Dissecting medical 'humanitarianism': recentring Indigenous and local know-how 'from below'}

History of medicine circles have moved beyond the protracted, and now tired, debate around whether public health/tropical medicine served as a handmaiden of colonialism or a humanitarian dimension of the otherwise despicable imperial enterprise. Yet against compelling evidence, contemporary practitioners of mainstream global health still hold that individual motivations are what matters. ${ }^{43}$ Meanwhile the WHO, positioned after the Second World War as a multilateral conduit to democratic, public governance in international health, has, in recent decades, become captured - fragmented, privatized (that is, channelling public monies into private, for-profit endeavours), and overshadowed by a set of corporate players and their powerful government partners who have turned global health into a technical intervention-based, profit-making, 'health security' bonanza under the veneer of humanitarian philanthropy. ${ }^{44}$ No players have been as prominent in championing this reorientation as Bill and Melinda Gates, the world's largest global health philanthropists, and their eponymous Seattle-based foundation, which has staked its fortune(s) on shaping the contemporary global health agenda.

Some of the most telling episodes of the West's COVID-19 response have involved the Gates duet. In April 2020, Melinda Gates lamented: 'It's going to be horrible in the developing world. ... Look at what's going on in Ecuador. They're putting bodies out on the street. You're going to see that in countries in Africa. ${ }^{45}$ Yet from early on, many African governments proved remarkably nimble in unleashing preventive and surveillance measures such as contact tracing (developed to deal with Ebola and other outbreaks, but jettisoned by donor neglect), unlike counterparts in North America and much of Europe, where dystopic scenes unfolded. ${ }^{46}$

Bill Gates, for his part, stepped up his vaccine 'benevolence'. In July 2020, the magnate warned: 'If we just let drugs and vaccines go to the highest bidder, instead of to the people and the places where they are most needed, we'll have a longer, more unjust, deadlier pandemic. We need leaders to make these hard decisions about distributing based on equity, not just on market-driven factors. ${ }^{37}$ Not only did he speak after most wealthy countries and the EU had already 'bought' their own vaccine and treatment access, but he called for modelling vaccine and drug distribution on the world's two largest public-private partnerships, which the Gates Foundation helped launch: Gavi (the Vaccine Alliance) and the Global Fund, which direct billions of public dollars annually into, respectively, Big Pharma-friendly vaccine purchasing and distribution, and AIDS-, tuberculosis-, and malaria-control efforts that provide lucrative private-sector contracts. It is true that these partnerships are not free-market-based: instead, they channel government contributions to large corporate interests. ${ }^{48}$ Furthermore, as has been announced, Gavi may do little to

\footnotetext{
${ }^{43}$ Abdallah S. Daar, Trillium Chang, Angela Salomon, and Peter A. Singer, 'Grand Challenges in Humanitarian Aid', Nature 559, no. 7713 (2018): 169-73.

${ }^{44}$ Anne-Emanuelle Birn and Laura Nervi, '(Re-)Making a People’s WHO,' American Journal of Public Health 110, no. 9 (2020): 1352-3, https://doi.org/10.2105/AJPH.2020.305806.

${ }^{45}$ 'Melinda Gates Said She Feared Coronavirus in Africa Would Lead to Dead Being Put Out in Street, as in Ecuador', Africa Check, 20 April 2020, https://africacheck.org/fbcheck/melinda-gates-said-she-feared-coronavirus-in-africa-would-lead-todead-being-put-out-in-street-as-in-ecuador/. Note that this fact-checking service is partially funded by the Gates Foundation: https://thegrayzone.com/2020/07/08/bill-gates-global-health-policy/.

${ }^{46}$ Jina Moore, 'What African Nations Are Teaching the West About Fighting the Coronavirus', New Yorker, 15 May 2020 , https://www.newyorker.com/news/news-desk/what-african-nations-are-teaching-the-west-about-fighting-the-coronavirus; Elias Biryabarema, 'Uganda's Tough Approach Curbs COVID, Even as Africa Nears 1 Million Cases', Reuters, 5 August 2020, https://www.reuters.com/article/us-health-coronavirus-uganda/ugandas-tough-approach-curbs-covid-even-as-africa-nears1-million-cases-idUSKCN251159.

${ }^{47}$ John Miller, 'Bill Gates Calls for COVID-19 Meds to Go to People Who Need Them, Not "Highest Bidder"', Reuters, 11 July 2020, citing video statement made by Bill Gates.

${ }^{48}$ Anne-Emanuelle Birn and Judith Richter, 'US Philanthrocapitalism and the Global Health Agenda: The Rockefeller and Gates Foundations, Past and Present', in Health Care Under the Knife: Moving Beyond Capitalism for Our Health, ed. Howard
} 
prevent powerful countries from purchasing and hoarding the bulk of vaccines. ${ }^{49}$ Gates's solution is hardly the equity-driven humanitarian utopia implied by most of the reporting. ${ }^{50}$

A historical understanding would help contemporary readers parse such prevarications and contradictions. Few, Doyle, and Richards illustrate the pervasiveness of the language and justification of medical humanitarianism in diverse epidemics, settings, and centuries, even as extraction, without recognition, of local and Indigenous knowledge proved decisive - against diverse forms of oppression and odds - in outbreak control. Sivaramakrishnan, meanwhile, discusses how Ayurvedic practitioners circa 1900 were (belatedly) mobilized by British colonial authorities who needed effective alternatives to their repressive plague policies in Bombay but were then marginalized in the postcolonial era. Today, the Indian state sees vaids and hakims as either quacks or fallbacks when biomedical measures are inadequate or fail, rather than engaging them as valuable practitioners. Similarly, although traditional Chinese medicine (TCM) and Qigong were shown (in reputable studies) to help China's mitigation of COVID-19 deaths in early 2020, TCM has been sidelined from therapeutic debates. ${ }^{51}$ Here, past colonial authorities appear to have been more open to medical pluralities than is the case today, when biomedicine's big business motives demarcate which tools and medical ideologies are profitable - and therefore acceptable.

This is not to say that history vindicates colonial power, but rather to reveal the complex and shifting impetus around how healers and their practices are legitimated. Indeed, historical analysis is critical to unpacking the elements of how imperialism and capitalism have facilitated, accelerated, and propagated epidemics - and impeded their control. In eighteenth-century colonial Guatemala, Few tells us, official and medical portrayals of inoculation campaigns against smallpox integrated a (paternalistic) Christian commitment to helping the poor and the sick by applying Enlightenment scientific knowledge and practices. Yet, as she highlights, Spanish colonialism directly and indirectly spread smallpox through war, dispossession, and coerced labour, atop new exposure to the pathogen. Most histories gloss over such factors and bypass the role of Indigenous self-determination and self-learning around variolation. In colonial Guatemala, Indigenous knowledge (medicinal beetles) was expropriated or blamed (ritual steam baths) for spreading disease and for usurping colonial power, and was thus brutally counteracted. Also left unsaid by mainstream accounts was the importance of maintaining the health of the Indigenous workforce to ensure their tax contributions to colonial coffers.

Richards similarly exposes how the humanitarian discourse deployed in tackling the Ebola outbreak of 2014 in West Africa furthered assumptions that Western/Global North knowledge and action are necessary to 'save' Africa (in effect reproducing neo-colonial power asymmetries as a form of humanitarianism).$^{52}$ But, as he shows for Sierra Leone, this version overlooks the fact that local observations and efforts were key to stemming the Ebola epidemic: understanding Ebola's communicability via touch, people either avoided contact or improvised protection with plastic bags, even when they had little power or wherewithal to mobilize medical services to rural areas. If only today's wave of mask-resisters and distance-defiers across high-income countries had the good judgement to observe and integrate such effective measures, rather than misguidedly viewing them as coercive. Such 'people's science' still reverberates: in April 2020, when Guayaquil, Ecuador, was witnessing horrific scenes of corpses and cardboard coffins amassing in the streets

\footnotetext{
Waitzkin and the Working Group on Health Beyond Capitalism (New York: Monthly Review Press, 2018). Along with other multi-stakeholder initiatives, Gavi and the Global Fund have upstaged the WHO, and contributed to its corporatization.

${ }^{49}$ Maria Cheng, 'Global Vaccine Plan May Allow Rich Countries to Buy More', Associated Press, 14 July 2020, https:// apnews.com/8903d5988545383d7c0b3796a9bcla14.

${ }^{50}$ Covered by outlets such as the Guardian, whose development reporting is funded by the Gates Foundation.

${ }^{51}$ Xingjiang Xiong, Pengqian Wang, Kelei Su, William C. Cho, and Yanwei Xing, 'Chinese Herbal Medicine for Coronavirus Disease 2019: A Systematic Review and Meta-Analysis’, Pharmacological Research 160 (2020), https://doi.org/10.1016/j.phrs. 2020.105056.

${ }^{52}$ See Anne-Emanuelle Birn, Yogan Pillay, and Timothy H. Holtz, Textbook of Global Health, 4th ed. (Oxford: Oxford University Press, 2017), chap. 8, for further explication.
} 
despite low official COVID-19 mortality, municipal authorities creatively clocked burial trends to signal excess (undiagnosed) deaths, an approach that is only belatedly being employed by statisticians in high-income countries to estimate undercounted COVID-19 deaths (albeit using official mortality data). ${ }^{53}$

Likewise, Doyle's work does much to dispel a prevailing 'victim story' around how Uganda has tackled AIDS (that is, needing to be rescued by George W. Bush's PEPFAR programme) ${ }^{54}$ Instead, he recounts how, within sub-Saharan Africa and globally, Uganda's early and extensive public health measures (including 'moral' exhortations) and success in mitigating HIV and AIDS raised its leader's profile domestically, within Africa, and at multilateral agencies, while being ignored or maligned in Washington. This, he argues, is a pre-echo of China's reframing of its early and controversial COVID-19 response, heavily touted by the Chinese government and praised in some public health circles even as the most powerful Western leaders have engaged in a non-stop smear campaign. Doyle may well go too far in his comparison. Just because China is often stereotyped and condemned by the West, it can hardly be considered a soft power 'from below' quietly stagemanaging its image on the global stage. ${ }^{55}$

Beyond disregarding local acumen, dominant narratives are also dismissive of the world's most responsive and bona fide medical humanitarianism: South-South medical solidarity from Cuba. Several hundred Cuban medics were quickly dispatched to tackle Ebola, while the US government and the WHO dithered. ${ }^{56}$ During COVID-19, Cuba's social justice-oriented South-South health cooperation has involved thousands of health personnel being sent to several dozen countries and has even extended to South-North solidarity with Lombardy and Andorra at the height of the pandemic crisis. ${ }^{57}$ In a cruel, displaced replay of the health worker shortage during Ebola (with more health personnel practising in OECD countries than in West Africa), these very personnel have been part of the huge and tragic toll of racialized health-worker COVID-19 deaths in the UK and elsewhere. ${ }^{58}$

These various historical insights around competing and innovative forms of knowledge 'from below' transpose to the COVID-19 situation and do much to illuminate it.

\section{Pandemics that changed the world: did they? Or did the world change to bring on pandemics?}

In a time that is momentous on so many fronts, the COVID-19 pandemic certainly appears to be unfolding at the cusp of a societal equivalent of statue-toppling (Brook reminds us of the assertion that the Black Death marked the invention of the modern world). And yet, elevating the historical gaze to prognostication, especially during pandemics, comes with perils more than possibilities. We might also reject the notion that history is deemed most useful when there are no biomedical

\footnotetext{
${ }^{53}$ Dan Collyns, “'Like the horror of war”: Mayor of Virus-Ravaged Ecuador City Calls for Drastic Response', Guardian, 22 April 2020, https://www.theguardian.com/world/2020/apr/22/ecuador-guayaquil-mayor-.

${ }^{54}$ Shane Doyle, 'Pandemics and Soft Power: HIV/AIDS and Uganda on the Global Stage', Journal of Global History, 15 (2020): 478-492.

${ }^{55}$ https://www.theguardian.com/commentisfree/2020/aug/03/covid-19-cold-war-china-western-governments-internationalpeace\#comment-142765269.

${ }^{56}$ E. B. Chaple and M. A. Mercer, 'The Cuban Response to the Ebola Epidemic in West Africa: Lessons in Solidarity', International Journal of Health Services 47 (2017): 134-49.

${ }^{57}$ During the COVID-19 pandemic, Cuban medical brigades have worked in multiple countries in the Caribbean, Latin America, Africa, and the Middle East, as well as southern Europe, and have been requested by Indigenous leaders in Manitoba, Canada. See B. Fernández, 'Cuba under Media Attack for Sending Doctors, Not Bombs, to Help Covid-19 Victims', FAIR, 14 April 2020, https://fair.org/home/cuba-under-media-attack-for-sending-doctors-not-bombs-to-helpCovid-19-victims/. The Trump administration has tried to halt this effort, which embarrasses and threatens what is left of the US's global health reputation.

${ }^{58}$ As Richards points out, in a bitter irony, the Sierra Leone diaspora in the UK was dying even as the statue of Edward Colston, who ran the Royal African Company in Sierra Leone that traded in enslaved Africans, was being toppled in early June 2020 .
} 
solutions. ${ }^{59}$ Given the responsibility of historians in constructing narratives, we should be mindful of how histories of human triumph over past pathogens and 'perpetrators' may distort our understanding of COVID-19's underlying drivers and amplify societal prejudices along the way. ${ }^{60}$ Green takes this a step further, suggesting that historians should change their practices in light of COVID-19, given that those who critique biomedical reductionism in other realms seem happy to assume it in the face of the unknown; she argues that we should instead more modestly recognize that the global social (political economy) order and its associated practices - linked to emergence of diseases across time - ought to be the central object of study. ${ }^{61}$ These dilemmas and debates aside, the blasts from the past highlighted in this collection shed light on the centrality of social sciences and humanities, well beyond the focus on technical knowledge, to approaching the dilemmas and crises that are being confronted across the world.

Being cognizant of how historical experience plays into the societal collective memory, as Doyle and Sivaramakrishnan detail, enables us not to mechanically map past onto present but to deepen understanding of why things are the way they are, as an underappreciated input to policy-making, coping, and preparedness alike. The assault on the humanities in many corners of the world, under the banner of austerity, is belied by the injection of a new societal urgency for history during the COVID crisis. ${ }^{62}$ Australia's mid-pandemic announcement of the doubling of university tuition fees for those studying humanities (while tuition fees for STEM fields are being slashed) is disconcerting, to say the least. ${ }^{63}$ Given Rice's discussion about how historical memory of 1918-20 influenza has shaped Australia's and New Zealand's current policies around COVID-19, this is particularly galling. ${ }^{64}$

On the other hand, perhaps everyone is a historian, or at least thinks a bit historically to help us face the social history of the unexpected amid the multiple pandemics through which we are living: racism; soaring unemployment and economic inequality; the climate crisis; and COVID-19 itself. In contrast to Phillips, I am not convinced that there has been a convergence of scientific and religious beliefs over time. ${ }^{65}$ Calls for days of prayer and fasting to defeat COVID-19 (and deflect attention from public policy shortcomings) not just by religious figures but also by political leaders in Bolivia, Louisiana, and Malawi, to name a few, have been widespread. Perhaps nowhere has the friction between science and religion been more problematic than Brazil, where the president's religious beckoning - amid his continuous flouting of scientific measures - has met with derision and furore, even as these practices have been widely heeded by his evangelical followers. A more sanguine alternative to popular resistance to the necessary uncertainties and tentativeness of scientific (not to mention historical) findings might be a welcoming of productive and deliberative tensions that allow a plurality of tolerant responses rather than the mistrust and rebuff that has been evidenced in many settings.

In the end we should not be overconfident of lessons and predictions, or of charting historychanging moments, as they may be forced, simplified, the wrong ones, marginally relevant, or illusory. ${ }^{66}$

\footnotetext{
${ }^{59}$ David S. Jones, 'COVID-19, History, and Humility', Centaurus 62, no. 2 (2020): 370-80.

${ }^{60}$ Nükhet Varlık, 'Rethinking the History of Plague in the Time of COVID-19', Centaurus 62, no. 2 (2020): $285-93$.

${ }^{61}$ Green, 'Emerging Diseases'.

${ }^{62}$ Robert Peckham, 'A Health Emergency Is No Time to Sideline the Medical Humanities', Times Higher Education, 10 February 2020, https:/www.timeshighereducation.com/opinion/health-emergency-no-time-sideline-medical-humanities.

${ }^{63}$ Radical Changes to Australia's Fees to Fund 39,000 New Places', Times Higher Education, 19 June 2020, https://www. timeshighereducation.com/news/radical-changes-australias-fees-fund-39000-new-places.

${ }^{64}$ Rice's own historical research was acknowledged as 'invaluable' in the development of the 2017 New Zealand Influenza Pandemic Plan: A Framework for Action, which in turn has guided the response to COVID-19.

${ }^{65}$ Howard Phillips, '17, '18, '19: Religion and Science in Three Pandemics, 1817, 1918, and 2019', Journal of Global History, 15 (2020): 434-443.

${ }^{66}$ D. R. Curtis and B. van Besouw, 'Not Learning from History: Learning from COVID-19', Wiley Network, 14 April 2020 , https://www.wiley.com/network/researchers/covid-19-resources-for-the-research-community/not-learning-from-historylearning-from-covid-19; Guillaume Lachenal and Gaëtan Thomas, 'COVID-19: When History Has No Lessons', History Workshop, 30 March 2020, http://www.historyworkshop.org.uk/covid-19-when-history-has-no-lessons/.
} 


\section{Conclusion: into a (global) future of past and present pandemics}

At this (perennial) time of reckoning around (neo-)colonialism, global capitalism, systemic antiBlack, anti-Brown, and anti-Indigenous racism, and their interactions with uneven exposure, susceptibility, death, and recovery from COVID-19, deep reflection is warranted. Just as pandemics, past and present, are lived differently by those with distinct life experiences, so there should be a concerted effort to further diversify the pool of historians writing pandemic histories. This topic begs for more Majority World perspectives, including junior scholars (and the responsibility of training them) ${ }^{67}$ Historians ourselves play a critical role in the call for open science, decolonizing history, and flipping the narrative. ${ }^{68}$

Historians must look outwards too. The pieces in this special issue employ the language of historians, but they also speak to health specialists, journalists, decision-makers, and the public at large. We appreciate the observation of the acclaimed Brazilian epidemiologist Cesar Victora, who is currently tracking COVID-19 as it burns diversely across Brazil, that (analogous to social historians) certain social epidemiologists like to go out and see the public - to glean what is truly going on. ${ }^{69}$ Indeed, some learned epidemiologists and public health leaders are well versed in the complexities of historical understanding (eschewing more prevalent rejection of history by scientists for its failure to provide causal or conclusive evidence) ${ }^{70}$ Now is an opportunity for such engagement to become the norm.

Returning to the initial critique of the present historo-demic, what - beyond creepy fascination and superficial lessons - does historical analysis provide to the contemporary observer and, perhaps above all, to the public health expert and politician? Since pandemics per force criss-cross the world and are historically and socially inscribed on the genome, understanding pandemics from a 'global history' perspective offers a crucial input to how we plot against, prevent, and make policy upon them today. The historian's reflex - saying that the past is infinitely complex ${ }^{71}$ - may not be helping our cause, but we can certainly contribute to forestalling, in a healthy way, the excessive agency granted to the virus and to the evolving science of the moment. Perspective, of course,

\footnotetext{
${ }^{67}$ I say this fully recognizing that I am part of the problem as a white Canadian historian (with US and European roots) of international/public health in Latin America.

${ }^{68}$ Leslie Chan, Budd Hall, Florence Piron, Rajesh Tandon, and Wanósts'a7 Lorna Williams, 'Open Science Beyond Open Access: For and With Communities, A Step towards the Decolonization of Knowledge’, Zenodo, 15 July 2020, http://doi.org/ 10.5281/zenodo.3946773; Amanda Behm, Christienna Fryar, Emma Hunter, Elisabeth Leake, Su Lin Lewis, and Sarah MillerDavenport, 'Decolonizing History: Enquiry and Practice', History Workshop Journal 89 (2020): 169-91, https://doi.org/10. 1093/hwj/dbz052. Fiocruz's Manguinhos journal is convening Latin-Americanist historians' perspectives on both Latin American and Global North countries (wherever they are based) in an effective flipping of narration (see https://bit.ly/ 3fxhr71). See also Birn, 'How to Have Narrative-Flipping History in a Pandemic'.

${ }^{69}$ Pan American Health Organization, 'Virtual Seminar Series on COVID-19, SDG-Health Related Targets, and Equity: Epidemiology and Inequalities in Brazil: The EpiCOVID19 Study', https://www.paho.org/collaborating-centers/ blog/virtual-seminar-series-on-covid-19-sdg-health-related-targets-and-equity-epidemiology-and-inequalities-in-brazil-theepicovid19-study/.

${ }^{70}$ See, for example, Nancy Krieger, Epidemiology and the People's Health: Theory and Context (New York: Oxford University Press, 2011); Nísia Trindade Lima, Silvia Gerschman, Flavio Coelho Edler, and Julio Manuel Suárez, Saúde e democracia: história e perspectivas do SUS (Health and Democracy: History and Perspectives of SUS [Brazil's national public healthcare system]) (Rio de Janeiro: Editora Fiocruz, 2005); Mary T. Bassett, 'No Justice, No Health: The Black Panther Party's Fight for Health in Boston and Beyond', Journal of African American Studies 23, no. 4 (2019): 352-63; Yogan Pillay, 'The National Health Services Commission Report of 1994: Lessons from the Past for the Reconstruction of Social Services in a PostApartheid South Africa', Psychology in Society 18 (1994): 34-46; Ashleigh R. Tuite, Christina H. Chan, and David N. Fisman. 'Cholera, Canals, and Contagion: Rediscovering Dr Beck's Report', Journal of Public Health Policy 32, no. 3 (2011): 320-33.

${ }^{71}$ Ironically, immunologists similarly characterize the immune system as extremely complicated. See Ed Yong, 'Immunology Is Where Intuition Goes to Die', Atlantic, 5 August 2020, https://www.theatlantic.com/health/archive/2020/ 08/covid-19-immunity-is-the-pandemics-central-mystery/614956/.
} 
requires time but, as historians of the present have instructed us, not that much time. ${ }^{72}$ Here's hoping that (historically) perspectivizing pandemics becomes as analogously useful and iconic a tool as randomizing in clinical trials ... and that historians who usually practise 'slow history' may recognize the occasional value of 'history in a hurry'.

Anne-Emanuelle Birn is Professor of Critical Development Studies and Global Health at the University of Toronto. Her research explores the history, politics, and political economy of international/global health, focusing on Latin American health and social justice movements, child health, and philanthrocapitalism. Her books include Marriage of Convenience: Rockefeller International Health and Revolutionary Mexico (2006), Comrades in Health: U.S. Health Internationalists, Abroad and at Home (2013), Oxford's Textbook of Global Health (2017), and Peripheral Nerve: Health and Medicine in Cold War Latin America (2020). A former Canada Research Chair in International Health, she was recognized as being among the top 100 Women Leaders in Global Health, and sits on the Independent Panel on Global Governance for Health.

\footnotetext{
${ }^{72}$ 'Introducing History of the Present', History of the Present 1, no. 1 (2011): 1-4, https://doi.org/10.5406/history present.1.1.0001.
}

Cite this article: Birn A.-E. 2020. Perspectivizing pandemics: (how) do epidemic histories criss-cross contexts? Journal of Global History 15: 336-349, doi:10.1017/S1740022820000327 